\title{
A New Softporn? Challenges to Religious Symbols as Form of Fashion Communication in Social Media
}

\author{
Rino F. Boer \\ Postgraduate Program \\ STIKOM LSPR \\ Jakarta, Indonesia \\ rino.fb@1spr.edu
}

\author{
Melsa N. D. \\ STIKOM LSPR \\ Jakarta, Indonesia
}

\begin{abstract}
Today social media are not only media for individual interaction but also for the construction of personal and community identity. The problem sometimes emerges when the construction of personal identity is in conflict with social values in public. This research focuses on the phenomenon of Jilboobs and those who wear skimpy dress on social media. It is called a soft pornography or softporn. Examples of both dress styles can be easily seen and students frequently see in their life and in society. The research questions are: Are there any differences in the perception of each dress style towards the figure of Muslim women among men students? And which one is more unacceptable as a representation of Muslim women either those who join in Jilboobs community or those who wear skimpy dress particularly the perception of men students who are studying in the tradition of Islamic education? Persons will speak with their dress. Dress style is symbolic form of communication; individual expression, social status, and religious magical conditions as dimension of independent variable $(X)$. The research used the dependent variable $(Y)$ with the perception concept, i.e. sensation, attention and interpretation. This research used survey on quantitative approach. Total respondents amount 109 students who are studying in the State Islamic University in Jakarta, and therefore, they have good understanding about Islam. It can be concluded that the respondents think that the two groups are significantly different; and the respondents are significantly unacceptable with the existence of Jilboobs compared to women who wear skimpy dress. This means that softporn associated with the use of certain religious symbols has greater rejection than the display that has been porn content from the beginning. Welcome to New Softporn Era!
\end{abstract}

Keywords—softporn, fashion, religious symbol, perception

\section{INTRODUCTION}

In postmodern era, it occurs many changes and development of life in society from technology, knowledge, culture to dress style. One change which occurs from time to time is the change of how persons wear dress. Wearing dress is a representation of self-image that they want to show to others as form of their self-presentation. Dress style can prevail for anyone from any social class because dress style of each person can form a person's self-identity. Particularly in the era where virtual identity becomes trend and it is easy to do through social media. Dress style intended in the research is directed to a group of women who wear jilboobs and skimpy dress. It does not only prevail for those who do not wear hijab can express their special dress style but also 'Muslim women' who can do the same. The more developed era is the more variations Muslim women dress. Style wearing hijab has been growing in society right now. There are many variations, and these can be combined to dress with the dress style of those who do not wear hijab.

Developing dress style for Muslim women results it to be in misunderstood by some people. Recently the phenomena of jilboobs emerges. The term jilboobs itself is the combination between hijab (headscarf) and boobs (bosom). The phenomena are frequently discussed on social media because it refers to the way a woman with scarf who wears a tight dress but forming her body particularly upper part of her body or bosom. Many who wear the dress think that such as headscarf is more attractive and trendy. In fact, the dress style is personal taste. Moreover, what a person wears will form the wearer's character and identity. It prevails for Muslim women as well. Hijab dress is a way of Muslim women to practice their religious teachings. However, when a woman decides to wear hijab, she has identified herself as a Muslim woman. As a Muslim woman, she will have her own dress style. Or in the other words, Muslim dress style indicates her own self-identity or personal dress style, and it should obey the dress code appropriate to provisions of the religious teachings. According to Hannie, in the beginning the term jilboobs is a satire term for certain Muslim dress for those who have lack of knowledge in Muslim dress. Some jilboobs communities can be found on Facebook, and some have the following address:

- Jilboobs-Indonesia is those who call their community Jilboobs Indonesia with total number of 1,908 likes and 1,938 followers.

- Jilboobid is those who call their community Jilboobid Indonesia with total number of 1,296 likes and 1,359 followers.

- A community which named Jilboobs Indonesia Community with likers 2.544 dan followers 2.552 .

There remained some similar communities that exist on Facebook until February 14, 2018. However, there were jilboobs websites which were no longer active such as jilboobsGaul shown to have 15,499 likers (recorded as the jilboobs website with the biggest number of likers) or jilboobs-style 
website. The jilboobs photos intended in the research are as follows (source: https://id.techniasia.com/jilboobs-pamer).

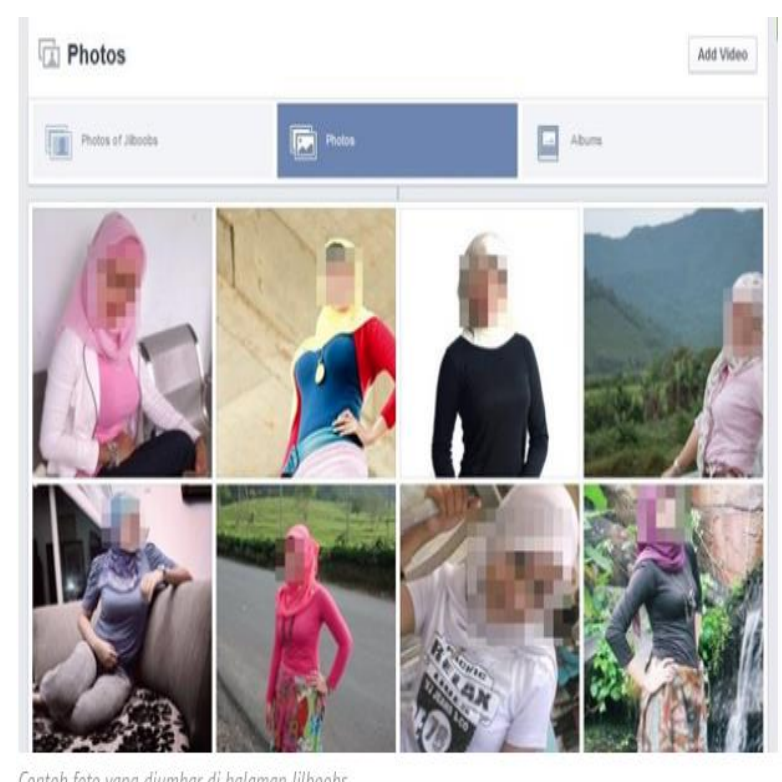

Fig. 1. Jilboobs photos.

On the other hand, social media users can easily see women community who generally wear sexy dress on Facebook. It can be concluded that the two dress styles do not reflect the religion for Islam particularly in the ode provision of Muslim women dress code. Based on the above research problem, the researchers are attracted to analyze the influence of how women wear jilboobs and skimpy dress towards the perception of men students who are still studying in the State Islamic University in Jakarta. In this matter, the researchers aim to do comparative studies on the phenomenon of women who wear jilboobs and those who wear skimpy dress.

Formulation of the research problems: "How does the influence of the way women wear jilboobs and skimpy dress towards the perception of men students in UIN Jakarta?"

The scope of the research will only focus on the research object on the influence of the way women wear jilboobs and skimpy dress towards the perception of men students in Jakarta, the phenomenon of women who wear jilboobs or those who wear skimpy dress is only limited to news coverage on online media particularly Facebook presenting the photos. The research was carried out in Ciputat, Tangerang towards the men students of Jakarta State Islamic University Faculty of Syariah and Laws, the Comparison of Islamic Schools Department particularly those from the 2013 Class. Therefore, the appraisal results of the respondents on the photos are assumed from those who understand the Islamic teachings in relation to Muslim dress for women.

Based on the results of literature review, it is found that studies conducted on the phenomenon of jilboobs mostly see in the aspect of users. Motivation, background of family, understanding on the legion of Islam, and the thinking process like what occurs in the users' mine so that they decide to use hijab dress dominates the studies. It is shown at least in the two following researches, i.e. Dress Style of Students in State Islamic University Sunan Kalijaga Yogyakarta Faculty of Syariah and Laws and Former Students of Islamic Boarding Schools" by Faiqoh in 2013 in State Islamic University Sunan Kalijaga and the research conducted by Widianto and Pratiwi in 2015 with the title of Audience Adaptation in Dress Style (Qualitative Descriptive Study on Trend of Jilboobs among Students in Yogyakarta) in State Islamic University Sunan Kalijaga Yogyakarta [1].

Someone uses fashion and clothing to send message about the wearer to others. In the delivery of the message it should be sent correctly. If the message does not arrive to the receiver, the process of communication will be considered incorrect. The impact for the message receiver is very important because the receivers will form social interaction, influence behavior, the way of thinking and emotional response to the message [2].

\section{A. Fashion and Lifestyle}

Fashion and apparel have several functions [2]:

1) Community Symbolic Communication: Fashion, clothing and apparel are known as cultural phenomenon and these are considered to have communicative functions. Fashion and apparel tie one community symbolically, and this shows that social accords over what to be worn is a social tie itself and in turn it will strengthen other social ties. The uniting function of fashion and clothing occurs to communicate the membership of a cultural group either those who become the members or not [2].

2) Individualistic Expression: Fashion, apparel and communication relate to belief about relationship between color and mood. It is unrefusable that fashion and apparel are used to reflect, strengthen, hide or build a person's mood. Moreover, buying and wearing new dress are more many documented, and it a way that an individual uses to change moods. This has been well documented as if it looks to make more and more people "addicted" over their feeling when they wear something new. Fashion and clothing are way individuals distinguish themselves as individuals who expresses some forms of their uniqueness [2].

3) Social Value or Status: Fashion and clothing are often used to indicate social status or value and individuals like to make appraisal towards others' social value or status based on what dress they wear. Status can be results or it develops from various sources, such as occupation, family, sex, gender, age or race. The social value can be permanent or changed. All cultures will use dress if it is not fashion to differ between men and women. Wearing dress is mostly to sign the difference between secular and religious class and some will use dress to sign the membership in different groups.

4) Magic-Religious Condition: Fashion and apparel here relates to dress wearing to show such as belief and belief power. Whether wearing dress and clothing permanently or temporarily, it can indicate the membership or affiliation to a 
social or religious group. Dress and clothing sign status or position in the groups, and these indicate strength, depth of religious belief or participation level and religious obedience. Based on the description, it is unavoidable that dress and clothing are not only a form of communication like language, but also these become identity whose meaning is not only individuals for those who wear them but also having social meaning. When dress and clothing have social meaning, and it means that the occurrence of wearing dress will tie the users with life values in the society and it will contain more serious consequence from the function to protect the users from hot, rain or cold.

\section{B. Perception}

Perception is the essence of communication, and interpretation is the core of perception being identical to decoding in communication process. Perception is called the core of communication because if our perception is not accurate, it is impossible for us to communicate effectively. Perception determines what message we choose and another message we ignore. Perception includes sensation through sensory devices (touch, sight, smell, taste, and hearing), attention and interpretation [3].

There are three stages of perception, i.e. [3]:

1) Sensation: Sensation refers to message sent to brain through sight, hearing, touch, taste and smell. Sense receptors of eyes, ears, skin and muscle, nose and tongue are the connector between human brain and its environment. Eyes make reaction to the wave of light, ears to the wave of sound, skin to temperature and pressure, nose to smell and tongue to taste. Moreover, the stimulations are sent to brain. The meaning of message sent to brain must be learned. All senses have role for the continuity of human communication.

2) Attention: Attention consciously processes small number of information from large number of information available. Before we respond or interpret whatever event or stimulus, at first we must pay attention to the event or stimulus. Perception requires the presence of an object to be perceived including others as well as oneself. The interesting stimulus tends to be considered more important and influential than those that do not attract our attention. In the attention there are some supporting factors among others as follows:

- The intensity of stimuli where we are interested to prominent stimuli than others.

- The intensity of novelty, new extraordinary and different things will attract our attention.

- The intensity of repetition, things are presented over and over again when accompanied by little variance will attract our attention.

3) Interpretation: Information comes from one or more human sense but individuals cannot interpret the meaning of each object directly. However, they interpret the meaning of information believed to represent the object. Therefore, it can be concluded from the above theory that perception is a process of human way of receiving information and then disgested and analyzed in his mind through all means of human senses such as what is seen, listened and felt. Communication is the transmission of information, ideas, emotion, skill and others by using symbols, words, pictures, figures, graphs and others. Action or transmission process are usually called communication [3].

Softporn could understand as pornography that is relatively obscure in content then its antecedent of hardcore porn [4]. In this case using of religious symbols (headscarf) it looks like tends to manipulate the common unconsciousness people that it will represent women religious by appearance. According to Carl I. Hovland, communication science is a systematic effort to explicitly formulate the principles of information delivery and the formation of a person's opinions and attitudes. Moreover, it is a process to change a person's behavior. The definition indicates that a communication object is not only a form of communication delivery but also the delivery of a person's options and attitudes [5].

Fashion or clothing are a form of communication that has been understood and done since humans recognize various materials and how to make clothes. The understanding continues to grow appropriate to the flow of thought that becomes trend in certain period of time. When trend of fashion style meets with religious teachings that regulate how to wear dress for its adherents, it will arise the differences of viewpoint. It includes the provisions on what it is proper to be seen and should be hidden from the view of improper persons. Women's clothing should not be tight because it can show the shape of their limbs. For a woman who wears dress but still wants to show her 'awrah when wearing dress, in essence she is naked. Women who wear dress but naked, who defiantly behave from religious teachings and morals as well as who invite others to imitate themselves belong to humans who will be the inhabitants of hell [6].

\section{TABLE I. DIFFERENCE BETWEEN LIFESTYLE OF MEN AND WOMEN.}

\begin{tabular}{|l|l|l|l|}
\hline & $\begin{array}{l}\text { Total Number of Early } \\
\text { Adult }\end{array}$ & Men & Women \\
\hline \hline Dress & 63 & 40 & 79 \\
\hline Music & 36 & 44 & 27 \\
\hline Stroll & 26 & 34 & 19 \\
\hline Personal appearance & 16 & 3 & 30 \\
\hline Savings & 14 & 11 & 16 \\
\hline Books & 8 & 7 & 10 \\
\hline Hobby & 8 & 12 & 3 \\
\hline Sports & 8 & 14 & 2 \\
\hline Vehicle & 7 & 12 & 3 \\
\hline
\end{tabular}

From above table, it can be concluded that in terms of following lifestyle, women are more dominant than men. It occurs because women are more concerned with appearance so that they look different and can reflect their self identity like what it is expected to follow a lifestyle that becomes a trend. Therefore, the hypotheses the researchers will make are as follows:

\section{Hypothesis 1}

Ho: There is no negative perception of UIN's men students in Jakarta against the way women wear jilboobs. 
Ha: There is negative perception of UIN's men students in Jakarta against the way women wear jilboobs.

\section{Hipotesis 2}

Ho: There is no negative perception of UIN's men students in Jakarta against the way women wear skimpy dress.

HA: There is negative perception of UIN'S men students in Jakarta against the way women wear skimpy dress.

\section{RESULT AND DISCUSSION}

In this research, the independent $t$ test is used to know whether there are any differences between average group of variable X1 (women wearing jilboobs dress) and variable X2 (women wearing skimpy dress). Significance value indicated by the table of average difference test (independent sample test) shows that Ho is rejected and it means both data of average variance in the group X1 or X2 is not identical. In other words, for the respondents there are any differences between women wearing skimpy dress and jilboobs dress against their perception on Muslim women.

\begin{tabular}{|c|c|c|c|c|c|c|c|c|c|c|}
\hline \multicolumn{11}{|c|}{ Independer } \\
\hline & & \multicolumn{2}{|c|}{$\begin{array}{l}\text { Levene's Testfor Equality of } \\
\text { Variances }\end{array}$} & \multicolumn{7}{|c|}{ Hisstior Equality of Heans } \\
\hline & & \multirow[b]{2}{*}{$\mathrm{F}$} & \multirow[b]{2}{*}{ Sig. } & \multirow[b]{2}{*}{$t$} & \multirow[b]{2}{*}{ of } & \multirow[b]{2}{*}{ Sig (2-ataled) } & \multirow{2}{*}{$\begin{array}{l}\text { Mean } \\
\text { Difarence }\end{array}$} & \multirow{2}{*}{$\begin{array}{l}\text { Stot Error } \\
\text { Difference }\end{array}$} & \multicolumn{2}{|c|}{$\begin{array}{l}95 \% \text { Confifence interal of it the } \\
\text { Difference }\end{array}$} \\
\hline & & & & & & & & & Lower & Upper \\
\hline & Equal variances assumed & .178 & .67 & $.24,168$ & 216 & .000 & $-18,99083$ & 7.78579 & $-20,59963$ & $-17,44202$ \\
\hline & Equal variances not assumed & & & $-24,168$ & 202,696 & .000 & -18,99083 & .78579 & $-20,54021$ & . 17,44445 \\
\hline
\end{tabular}

Moreover, from the ANOVA F-test in the following table, it shows that both variables simultaneously affect students' perception about the figure of Muslim women depicted through the two variables.

\begin{tabular}{|c|c|c|c|c|c|c|}
\hline \multicolumn{7}{|c|}{ ANOVA $A^{3}$} \\
\hline \multicolumn{2}{|c|}{ Model } & Sum of Sauares & Df & Mean Square & $\mathrm{F}$ & sig: \\
\hline \multirow[t]{3}{*}{1} & Rerression & 284,937 & 2 & 142,469 & 4,578 & $012^{\mathrm{b}}$ \\
\hline & Residual & 3298,879 & 106 & 31,122 & & \\
\hline & Total & 3583,817 & 108 & & & \\
\hline \multicolumn{7}{|c|}{ a. Dependent Variable: PERSEPSI } \\
\hline \multicolumn{7}{|c|}{ b. Predictors: (Constant), MINIM, JLBOOBS } \\
\hline
\end{tabular}

To see partial differences of each independent variable toward dependent variable, regression test is carried out and the results shown in the following table.

\begin{tabular}{|c|c|c|c|c|c|c|}
\hline \multicolumn{7}{|c|}{ Coefficients ${ }^{\mathrm{a}}$} \\
\hline & & \multicolumn{2}{|c|}{$\begin{array}{l}\text { Unstandardized } \\
\text { Coefficients }\end{array}$} & \multirow{2}{*}{$\begin{array}{l}\text { Standardized } \\
\text { Coefficients } \\
\text { Beta }\end{array}$} & \multirow[b]{2}{*}{$t$} & \multirow[b]{2}{*}{ Sig. } \\
\hline \multicolumn{2}{|c|}{ Model } & B & Std. Error & & & \\
\hline \multirow[t]{3}{*}{1} & (Constant) & 61,003 & 7,924 & & 7,699 &, 000 \\
\hline & JILBOOBS &,- 245 &, 083 &,- 277 & $-2,969$ &, 004 \\
\hline & MINIM &, 058 & ,107 & ,050 & ,541 &, 590 \\
\hline
\end{tabular}

From the output results in the above table, linear regression equation value is as follows:

$$
\mathrm{Y}=61,003-0,245 \mathrm{X}_{1}+0,058 \mathrm{X}_{2}
$$

The conclusion is that the $\alpha_{1} X_{1}$ value in the way women wear jilboobs dress is negative -0.245 and the hypotheses result is significant. The data that can be analyzed and have Muslim. However, if a woman wears hijab, she looks like a Muslim woman. However, her dress is improper, so we will be significant influence or significance are variable $X_{1}$, i.e. the way women wear jilboobs dress, and for the variable $\mathrm{X}_{2}$, i.e. how women wearing skimpy dress show insignificant influence. Therefore, it can be concluded that for the respondents the more many posting photos on social media or appearance wear jilboobs dress in public places, the more many negative perceptions of the respondents against their figure as Muslim women. On the contrary, for women who wear skimpy dress, the respondents doe not see it as a negative picture against the figure of Muslim women.

The conclusion can be drawn from each relationships between variables $X_{1}$ against $Y$ and variable $X_{2}$ against $Y$ of the two variables that there are significant differences between variable $X_{1}$ and $X_{2}$ against variable $Y$. Where in variable $X_{1}$ there is negative perception on the way women wear jilboobs dress. However, in variable $\mathrm{X}_{2}$ it is not found negative perception on the way women wear skimpy dress against men students of UIN Jakarta.

For complete description of the data, the following will be presented some qualitative viewpoints which informants have given. With initial names, some informants convey the following information:

The informant A has the following opinion:

"From the religious viewpoint it has explained that for example, wearing hijab dress should be closed and does not show 'awrah like that. So, the way she wears her dress show that she is the figure of a Muslim woman."

Informant B also conveys similar thing with more complete explanation as follows:

"It is better for women wearing skimpy dress because for jilboobs she wears hijab or Muslim dress but she shows her body shape, so it raises negative thinking from those around her. So, if a woman wears skimpy dress, it is real condition that she looks like that. It has been her habit, and therefore, it is possible because there is foreign culture in her fashion."

Informant $\mathrm{C}$ prefer to see women wearing skimpy dress than jilboobs because the last women use religious symbols (hijab) and it is considered very disturbing:

"Those who carry religion issues are definitely jilboobs. Yes, they are. It is because a woman uses Islamic attribute in her dress, but the way she wears dress is totally wrong. So maybe I see jilboobs that she wants to wear a closed dress but it is improper. I see that her wearing dress is rather disturbed. The women want to wear hijab dress but their body shape is shown anywhere. So, I prefer to see women wearing skimpy dress. I mean that it remains more reasonable because she does not bring religion."

In more explicitly, informant $\mathrm{D}$ submits his rejection against the figure of Muslim women wearing jilboobs dress. According to the informant:

"I prefer to see women wearing skimpy dress. If she wears skimpy dress it is probably that she is Christian, Catholic or

back again that she brings religion. Moreover, if these women are on social media anyone can see them." 
A Muslim woman can be said a Muslim woman if she is not only seen from the way she wears her hijab dress appropriate to Islamic teachings, but also her wearing dress can be seen from her religious obedience. For muslim women wearing skimpy clothes and jilboobs, it can not be said that the two groups do not have any indication of their religious obedience to their religion, for the informant, dress can not be the only one indication of a person's obedience. At least Informant B has expressed his viewpoint:

"Her wearing dress cannot show her religious obedience. It is because if we compare between jilboobs and those wearing skimpy dress, it is possible that those wearing skimpy dress are more obedient in their worship than jilboobs or otherwise."

A similar one is also delivered by Informants $\mathrm{E}$ as follows:

"In my opinion, the religious obedience could not be seen from how women wear her dress because it is not necessarily that those wearing skimpy dress do not obey Islam teachings like prayer. Dress cannot indicate a person's obedience. Maybe her knowledge in the way Muslim women wear their dress is less understanding, but it is not necessarily that they do not pray well."

\section{CONCLUSION}

Based on the results of quantitative and qualitative analysis in this research, it can be concluded that the five informants have similar viewpoint on why they prefer wearing skimpy dress compared to jilboobs dress. The reason behind the statement that jilboobs dress does not represent the figure of Muslim women because it does not obey the provisions of Islamic teachings. Women wearing jilboobs dress show their body shape despite they wear hijab. They still show their body shape particularly their bosom. Islam teaches that Muslim women in their dress code should not show their body shape and their 'awrah and on the contrary, they should not wear a tight dress but a loose and long dress. Some people looks like they could 'understand' and as if accept this in fact because of what we found as a new form of soft porn or the concepts of pornography present through subliminal consciousness of people used the religious symbols. It is truly dangerous for all of us!

\section{REFERENCES}

[1] F.R. Widianto, F.D. Pratiwi, "Audience adaptation dalam gaya berpakaian (studi deskriptif kualitatif trend jilboobs pada mahasiswa Yogyakarta)," Profetik. vol. 8(2) 2015.

[2] M. Barnard, Fashion as communication. London: Routledge, 2002.

[3] D. Mulyana, Komunikasi lintas budaya. Bandung: Rosda Karya, 2011.

[4] J.A. Reisman, "Soft porn" plays hardball. Lafayette, Lousiana: Huntington House Publisher, 1991.

[5] O.U. Effendi, Ilmu komunikasi teori dan praktek. Bandung: PT Remaja Rosdakarya, 2009.

[6] A.U. Abdillah, Muslim hebat. Tangerang: Penerbit Arrisalah, 2015.

[7] D. Chaney, Lifestyle. London: Routledge, 1996. 